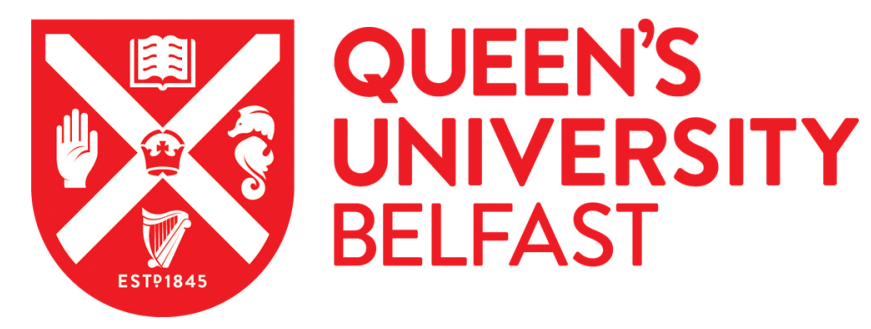

\title{
Evaluation of Cyclic Deformation Behavior of Laser-welded Shape Memory NiTi Alloys at Different Working Temperatures
}

Chan, C. W., \& Man, H. C. (2014). Evaluation of Cyclic Deformation Behavior of Laser-welded Shape Memory NiTi Alloys at Different Working Temperatures. Paper presented at The 33rd International Congress on Applications of Lasers \& Electro-Optics (ICALEOR), San Diego, United States. https://de356I4tocdyu.cloudfront.net/pdf/ICALEO\%20Advance\%20Program\%20Web.pdf

Document Version:

Early version, also known as pre-print

Queen's University Belfast - Research Portal:

Link to publication record in Queen's University Belfast Research Portal

\section{General rights}

Copyright for the publications made accessible via the Queen's University Belfast Research Portal is retained by the author(s) and / or other copyright owners and it is a condition of accessing these publications that users recognise and abide by the legal requirements associated with these rights.

Take down policy

The Research Portal is Queen's institutional repository that provides access to Queen's research output. Every effort has been made to ensure that content in the Research Portal does not infringe any person's rights, or applicable UK laws. If you discover content in the Research Portal that you believe breaches copyright or violates any law, please contact openaccess@qub.ac.uk. 


\title{
EVALUATION OF CYCLIC DEFORMATION BEHAVIOR OF LASER-WELDED SHAPE MEMORY NITI ALLOYS AT DIFFERENT WORKING TEMPERATURES
}

Paper ID: 405

\author{
Chi-Wai Chan ${ }^{1}$, Hau-Chung Man ${ }^{2}$ \\ ${ }^{1}$ School of Mechanical and Aerospace Engineering, Queen's University Belfast, Northern Ireland, UK \\ ${ }^{2}$ Department of Industrial and Systems Engineering, The Hong Kong Polytechnic University, Hung Hom, \\ Kowloon, Hong Kong, China
}

\begin{abstract}
Post-weld heat-treatment (PWHT) has been established as one of the cost-effective ways to improve the functional properties, namely shape memory and super-elastic effects (SME and SE), of laser-welded NiTi alloys. However, the functional performance of the laser-welded joint at different working temperatures has not been explored yet. The purpose of this study is to investigate the effect of different working temperatures on the functional properties of the laser-welded NiTi alloys before and after PWHT by applying cyclic deformation tests. Two laserwelded samples: as-welded and heat-treated sample (after PWHT at $350{ }^{\circ} \mathrm{C}$ or $623 \mathrm{~K}$ ) were tested in this work at room temperature, $50{ }^{\circ} \mathrm{C}$ (or $323 \mathrm{~K}$ ) and $75^{\circ} \mathrm{C}$ (or $348 \mathrm{~K}$ ) respectively. The samples were cyclically loaded and unloaded for 10 cycles up to $4 \%$ strain. The critical stress to induce the martensitic transformation and the residual strain after the cyclic tests were recorded. The results indicate that the heattreated sample exhibited better functional properties than the as-welded sample at room temperature and 50 ${ }^{\circ} \mathrm{C}$ (or $323 \mathrm{~K}$ ). However, both the as-welded and heattreated samples failed in the cyclic tests at $75{ }^{\circ} \mathrm{C}$ (or $348 \mathrm{~K})$. These findings are important to determine the feasible working temperature range for the laserwelded NiTi components to exhibit desirable functional properties in engineering applications involving cyclic loading.
\end{abstract}

\section{Introduction}

Since the discovery of the shape memory and superelastic effects (SME and SE), the near-equiatomic Nirich NiTi alloys have been extensively used in various engineering domains, i.e. from implantable biomedical devices and actuators to aerospace applications [1-3]. SME and SE are direct consequences of the reversible martensitic transformation between austenite (hightemperature phase) and martensite (low-temperature phase). SME for which it is named refers to the ability of martensitic NiTi to recover to their original shape in the austenitic state upon heating. SE allows NiTi alloys to sustain up to $8 \%$ strain without permanent deformation. Although NiTi alloys possess these unique functional properties, namely SME and SE, which mark them out from the conventional engineering materials, the difficulty in fabrication, particularly joining with itself and other materials, greatly impedes the design of more complex and efficient engineering products involving NiTi alloys as the core component.

Laser welding is one of the most guaranteed joining processes for NiTi alloys because of its high precision and small heat input, which minimizes the effect of heat distortion and the size of weld zone (WZ) and heat-affected zone (HAZ) [4-7]. However, it is welldocumented that the functional properties of the laserwelded NiTi components are degraded to a certain extent due to the microstructural disparity between the WZ, HAZ, and base metal (BM). Certain postprocessing treatments are still required to recover the integrity of the laser weld-joint to retain desirable functional properties.

Heat-treatment is commonly used to optimize the functional properties of $\mathrm{NiTi}$ alloys by precipitation effects. The precipitates can be appearing in the sequence of $\mathrm{Ni}_{4} \mathrm{Ti}_{3}, \mathrm{Ni}_{3} \mathrm{Ti}_{2}$ and $\mathrm{Ni}_{3} \mathrm{Ti}$ between the heattreatment temperatures from $350{ }^{\circ} \mathrm{C}$ to $800{ }^{\circ} \mathrm{C}(623 \mathrm{~K}$ to $1073 \mathrm{~K}$ ) [8]. It has been widely recognized that intermediate treatment temperatures, namely $350{ }^{\circ} \mathrm{C}$ to $450{ }^{\circ} \mathrm{C}(623 \mathrm{~K}$ to $723 \mathrm{~K})$, have a profound impact on the functional properties of NiTi alloys because of the precipitation of coherent and small-sized $\mathrm{Ni}_{4} \mathrm{Ti}_{3}$ precipitates. The effect of $\mathrm{Ni}_{4} \mathrm{Ti}_{3}$ precipitates on the functional properties of the laser-welded NiTi wires in such intermediate treatment temperature range has been comprehensively investigated in our previous work $[6,7]$. The experimental findings point to the fact that the laser-welded wires with post-weld heat treatment (PWHT) at $350{ }^{\circ} \mathrm{C}(623 \mathrm{~K})$ exhibited the most advantageous functional properties than those heat-treated at other temperatures. However, such performance measurements are only valid at room temperature, and whether the good effect of PWHT at $350{ }^{\circ} \mathrm{C}(623 \mathrm{~K})$ can improve the functional properties 
at higher test temperatures is still unknown. This is the motivation for this study since NiTi engineering components are often operating at higher temperatures.

\section{Experimental Details}

\section{Material and Procedure of Laser Welding}

The material used was commercial Ti-55.91 wt \% Ni wire of diameter $0.5 \mathrm{~mm}$ (purchased from Johnson Matthey). Butt weld was made on two pieces of the NiTi wires using a $100-W$ CW fibre laser (Model SP100C-0013, output wavelength $1091 \mathrm{~nm}$, in-focus spot size $46 \mu \mathrm{m})$. The process parameters were optimized by using Taguchi experiment (one of Design of Experiments methods) and were obtained as: $72 \mathrm{~W}$ laser power, $115 \mathrm{~ms}$ welding time, + $0 \mathrm{~mm}$ defocusing, and $25 \mathrm{~L} / \mathrm{min}$ of argon flow rate. After laser welding, post-weld heat-treatment (PWHT) was carried out to the laser-welded samples. The PWHT temperature was chosen as $350{ }^{\circ} \mathrm{C}(623 \mathrm{~K})$. The selection process for the particular PWHT temperature used in this study was detailed in elsewhere [6]. The PWHT was done by keeping the laser-welded samples in the furnace at the target temperature for $3600 \mathrm{~s}$, followed by water quenching. There were two types of samples: aswelded sample and heat-treated sample (which refers to the laser-welded sample after PWHT) being tested and compared in this study. The weldments possessed three distinct and identifiable zones, namely weld zone (WZ), heat-affected zone (HAZ) and base material (BM).

\section{Cyclic Deformation Tests at Different Temperatures}

The functional behavior of the samples was tested using an Instron tensile machine equipped with a temperature-controlled chamber. The strain rate was 3 x $10^{-5} \mathrm{~s}^{-1}$. Two types of cycle deformation tests were carried out in this study. The samples in the first test were repetitively loaded to $4 \%$ and then unloaded to 5 $\mathrm{MPa}$ for 10 cycles, while incremental strains from 0.7 $\%$ to $4.0 \%$ were applied to the samples in the second test, i.e. the samples were incrementally loaded from $0.7 \%, 1.5 \%, 2.5 \%$ and $4.0 \%$ respectively, followed by unloading to $5 \mathrm{MPa}$. The tests were carried out at three different temperatures: room temperature $\left(25{ }^{\circ} \mathrm{C}\right.$ or $298 \mathrm{~K}), 50{ }^{\circ} \mathrm{C}(323 \mathrm{~K})$, and $75^{\circ} \mathrm{C}(348 \mathrm{~K})$.

\section{Thermal Phase Transformation Measurements}

The phase transformation temperatures, namely austenitic starting/finishing temperature $\left(\mathrm{A}_{\mathrm{S}} / \mathrm{A}_{\mathrm{F}}\right)$ and martsensitic starting/finishing temperatures $\left(\mathrm{M}_{\mathrm{S}} / \mathrm{M}_{\mathrm{F}}\right)$ of the WZ and BM in the samples before and after PWHT have been characterized by differential scanning calorimetry (DSC) in our previous work [6], and the results are shown in Table 1.

Table 1 Phase transformation temperatures of the WZ and $\mathrm{BM}$ in the laser-welded samples before and after PWHT

\begin{tabular}{|c|c|c|c|c|}
\hline \\
\hline & $\begin{array}{c}\text { WZ } \\
\text { (Before } \\
\text { PWHT) }\end{array}$ & $\begin{array}{c}\text { WZ } \\
\text { (After } \\
\text { PWHT) }\end{array}$ & $\begin{array}{c}\text { BM } \\
\text { (Before } \\
\text { PWHT) }\end{array}$ & $\begin{array}{c}\text { BM } \\
\text { (After } \\
\text { PWHT) }\end{array}$ \\
\hline $\begin{array}{c}\text { Austenitic } \\
\text { Starting } \\
\text { Temperature } \\
\left(\mathrm{A}_{\mathrm{s}}\right)\end{array}$ & $\begin{array}{l}-20.6^{\circ} \mathrm{C} \\
(252.4 \mathrm{~K})\end{array}$ & $\begin{array}{c}22.6^{\circ} \mathrm{C} \\
(295.6 \mathrm{~K})\end{array}$ & $\begin{array}{c}-3.6^{\circ} \mathrm{C} \\
(269.4 \mathrm{~K})\end{array}$ & $\begin{array}{c}8.3^{\circ} \mathrm{C} \\
(281.3 \mathrm{~K})\end{array}$ \\
\hline $\begin{array}{c}\text { Austenitic } \\
\text { Finishing } \\
\text { Temperature } \\
\left(\mathrm{A}_{\mathrm{F}}\right)\end{array}$ & $\begin{array}{c}-5.8^{\circ} \mathrm{C} \\
(267.2 \mathrm{~K})\end{array}$ & $\begin{array}{c}33.9^{\circ} \mathrm{C} \\
(306.9 \mathrm{~K})\end{array}$ & $\begin{array}{c}8.8^{\circ} \mathrm{C} \\
(281.8 \mathrm{~K})\end{array}$ & $\begin{array}{c}28.2^{\circ} \mathrm{C} \\
(301.2 \mathrm{~K})\end{array}$ \\
\hline $\begin{array}{l}\text { Martensitic } \\
\text { Starting } \\
\text { Temperature } \\
\left(\mathrm{M}_{\mathrm{s}}\right)\end{array}$ & $\begin{array}{l}-40.5^{\circ} \mathrm{C} \\
(232.5 \mathrm{~K})\end{array}$ & $\begin{array}{c}5.3^{\circ} \mathrm{C} \\
(278.3 \mathrm{~K})\end{array}$ & $\begin{array}{c}2.2^{\circ} \mathrm{C} \\
(275.2 \mathrm{~K})\end{array}$ & $\begin{array}{c}20.6^{\circ} \mathrm{C} \\
(293.6 \mathrm{~K})\end{array}$ \\
\hline $\begin{array}{l}\text { Martensitic } \\
\text { Finishing } \\
\text { Temperature } \\
\quad\left(\mathrm{M}_{\mathrm{F}}\right)\end{array}$ & $\begin{array}{l}-52.3^{\circ} \mathrm{C} \\
(220.7 \mathrm{~K})\end{array}$ & $\begin{array}{c}-4.7^{\circ} \mathrm{C} \\
(268.3 \mathrm{~K})\end{array}$ & $\begin{array}{c}-7.0^{\circ} \mathrm{C} \\
(266.0 \mathrm{~K})\end{array}$ & $\begin{array}{c}1.5^{\circ} \mathrm{C} \\
(274.5 \mathrm{~K})\end{array}$ \\
\hline
\end{tabular}

Phase transformation temperatures are the important variable to influence the functional properties of the laser-welded samples. The samples would either exhibit the shape memory effect (SME) or superelasticity (SE) or a combination of them at different test temperatures. SME would occur if the test temperature is below the $\mathrm{M}_{\mathrm{F}}$ while $\mathrm{SE}$ would occur if the test temperature is above $A_{F}$. In the case where the test temperature falls between the $\mathrm{M}_{\mathrm{F}}$ and $\mathrm{A}_{\mathrm{F}}$, a combination of SME and SE would occur [9].

\section{Results and Discussions}

Figure 1 (a-f) shows the cyclic stress-strain curves for the as-welded and heat-treated samples after loading and unloading to $4 \%$ at different cycles $(1,2,5$ and 10) and at different test temperatures (at room temperature, $50{ }^{\circ} \mathrm{C}$ and $75{ }^{\circ} \mathrm{C}$ ) respectively. In the cyclic stressstrain curves, two distinctive features, stress plateau and residual strain, are the important measures for the functional properties of NiTi alloys. From the phenomenal point of view, the stress plateau signifies the stress-induced martensitic transformation (SIMT) process from austenite to martensite (upper plateau) or vice versa (lower plateau). Residual strain is interpreted as the amount of plastic strain left in the samples after the cyclic deformation tests. As a general rule, the smaller the residual strain, the better is the SE. 

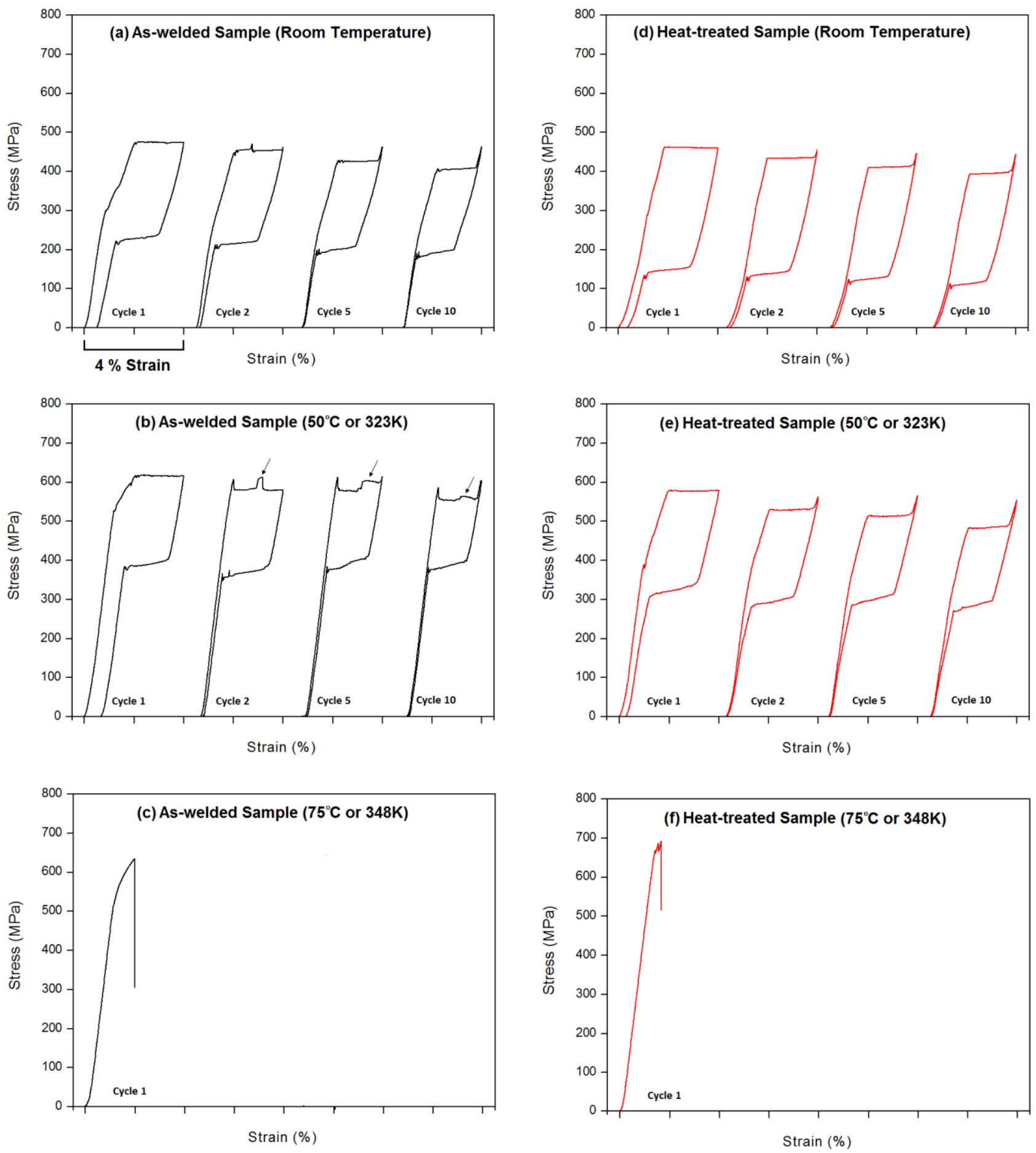

Figure 1 (a-f) - Cyclic stress-strain curves for the (a-c) as-welded and (d-f) heat-treated samples after loading and unloading to $4 \%$ strain for 10 cycles at different test temperatures 
There is one common characteristic which could be observed from the cyclic stress-strain curves. Both the upper and lower plateau stress levels were found to increase with increasing test temperature. But this relationship was only valid between the room temperature and $50{ }^{\circ} \mathrm{C}$. At $75{ }^{\circ} \mathrm{C}$, the as-welded and heat-treated samples fractured in the first cycle without showing the stress plateau. On the other hand, noticeable residual strain can be seen from the samples when testing at room temperature and $50{ }^{\circ} \mathrm{C}$. At room temperature, the residual strain of the as-welded sample was slightly higher than that of the heat-treated sample, i.e. about $0.2 \%$. However, the difference of residual strain between the as-welded and heat-treated samples increased substantially to about $0.7 \%$ when raising the working temperature to $50{ }^{\circ} \mathrm{C}$. The residual strain of the as-welded sample further increased while that of the heat-treated sample further decreased, compared with the samples tested at room temperature. The aforementioned observations will be discussed in detail in the following subsections.

\section{Effect of Test Temperature on the Stress Plateau}

The increase of plateau stress level with increasing test temperature for NiTi alloys can be described by the Clausius-Clapeyron relationship which is expressed by the following equation:

$$
\mathrm{d} \sigma / \mathrm{dT}=-\triangle \mathrm{H} / \mathrm{T} \varepsilon_{\mathrm{o}}
$$

Where $d \sigma$ is the change in plateau stress level, dT is the change in test temperature, $\triangle H$ is the latent heat of transformation, $\mathrm{T}$ is the test temperature and $\varepsilon_{\mathrm{o}}$ is the transformational strain [10]. The $d \sigma / d T$ values (for the upper and lower plateau stress levels) of the as-welded and heat-treated samples in this work are calculated and tabulated in Table 2.

Table 2 The do/dT values for the upper and lower plateau stress levels of the as-welded and heat-treated samples between room temperature and $50{ }^{\circ} \mathrm{C}$

\begin{tabular}{|l|c|c|}
\cline { 2 - 3 } \multicolumn{1}{c|}{} & $\begin{array}{c}\text { As-welded } \\
\text { Sample }\end{array}$ & $\begin{array}{c}\text { Heat-treated } \\
\text { Sample }\end{array}$ \\
\hline $\begin{array}{l}\mathrm{d} \sigma / \mathrm{dT} \text { for the Upper } \\
\text { Plateau Stress Level }\end{array}$ & $5.7 \mathrm{MPa} /{ }^{\circ} \mathrm{C}$ & $4.1 \mathrm{MPa} /{ }^{\circ} \mathrm{C}$ \\
\hline $\begin{array}{l}\mathrm{d} \sigma / \mathrm{dT} \text { for the Lower } \\
\text { Plateau Stress Level }\end{array}$ & $6.4 \mathrm{MPa} /{ }^{\circ} \mathrm{C}$ & $7.2 \mathrm{MPa} /{ }^{\circ} \mathrm{C}$ \\
\hline
\end{tabular}

The calculation results indicate that the $d \sigma / d T$ values for the as-welded and heat-treated samples were within the typical range reported in literature, i.e. the documented $\mathrm{d} \sigma / \mathrm{dT}$ values for NiTi alloys vary between 3 and $20 \mathrm{MPa} /{ }^{\circ} \mathrm{C}$. In the case of testing at $75{ }^{\circ} \mathrm{C}$, the disappearance of stress plateau before fracture because the critical stress required to trigger the SIMT process became higher than that to cause fracture of the weldjoint. As such, no stress plateau existed in the samples tested at $75{ }^{\circ} \mathrm{C}$.

\section{Effect of Test Temperature on the Residual Strain}

The residual strain accumulated in the stress-strain curves after cyclic tests is an indicator to evaluate the deformation behavior of NiTi alloys. The deformation behavior of the laser-welded NiTi alloys before and after PWHT have been explicitly described in our previous work [6]. To briefly summarize, the residual strain in the as-welded sample at room temperature is predominantly contributed by local plastic deformation in WZ and HAZ. These regions would be plastically deformed when straining beyond a particular point prior to the start of the SIMT process (usually between $0.6 \%$ and $0.8 \%$ strain) [6]. The local plastic deformation in the welded regions is signified by the deviation from linearity between $0.7 \%$ and $1.6 \%$ strain in the magnified stress-strain curve for the aswelded sample at room temperature (see Figure 2 below).

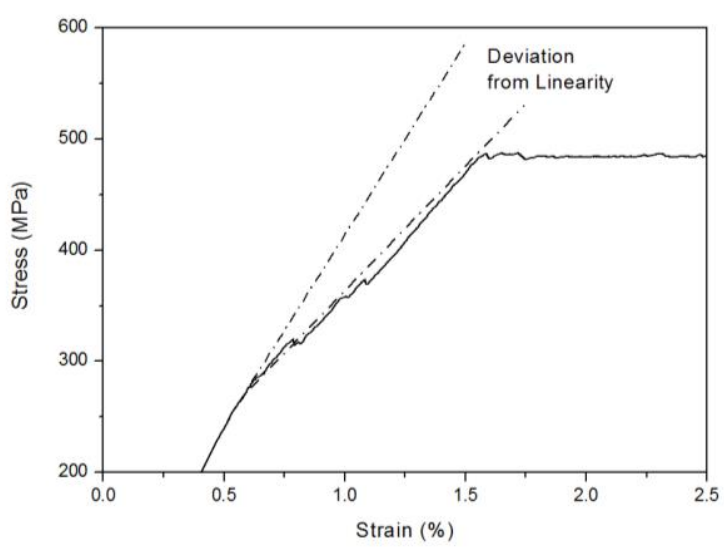

Figure 2 - Magnified stress-strain curve for the aswelded sample at room temperature

In comparison with the as-welded sample, the deformation behavior of the heat-treated sample is more complicated because both the austenite and twinned (or thermally-induced) martensite coexist in the base metal (BM) at room temperature as it lies between the austenite starting $\left(\mathrm{A}_{\mathrm{s}}\right)$ and austenite finishing $\left(A_{F}\right)$ temperatures (see Table 1). On top of the local plastic deformation in the welded regions, detwinning of the twinned martenite in the BM would be the additional source to the residual strain. Detwinning in NiTi alloys is the unique deformation process which is responsible for the shape memory effect (SME). The deformation caused by detwinning is reversible which can be recovered upon subsequent 
heating to a temperature above $A_{F}$ after the deformation. Surprisingly, even though the heat-treated sample contained the detwinned martensite in the BM, its residual strain was still less than that in the aswelded sample after the cyclic tests. This could be explained by the presence of small-sized $\mathrm{Ni}_{4} \mathrm{Ti}_{3}$ precipitates which coherently precipitate in the welded regions of the heat-treated sample after PWHT. It is well known that the $\mathrm{Ni}_{4} \mathrm{Ti}_{3}$ precipitates can suppress plastic deformation and hence improve the functional properties of NiTi alloys. The presence of $\mathrm{Ni}_{4} \mathrm{Ti}_{3}$ precipitates in the welded regions after PWHT can increase the resistance to plastic flow, and hence reduce the portion of residual strain attributed to the local plastic deformation.
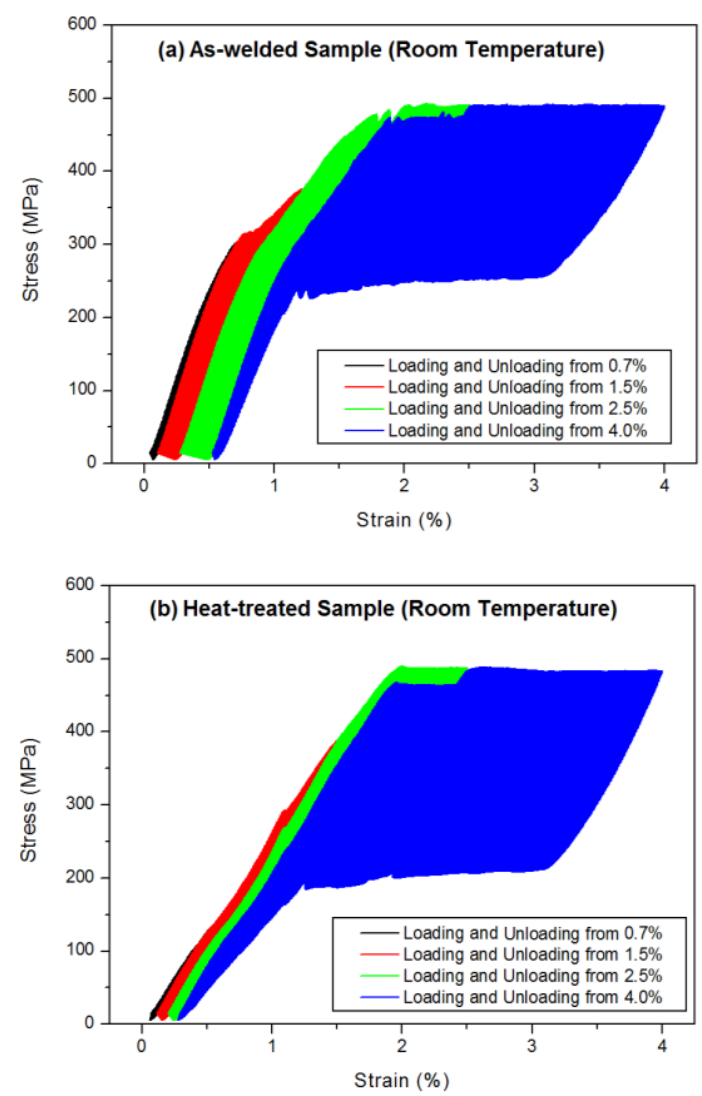

Figure 3(a-b) - Cyclic stress-strain curves for the (a) as-welded and (b) heat-treated samples after incrementally loading and unloading from $0.7 \%$ to 4.0 $\%$ strain at room temperature

To experimentally verify the effect of $\mathrm{Ni}_{4} \mathrm{Ti}_{3}$ precipitates on resisting local plastic deformation, the as-welded and heat-treated samples were tested (loaded/unloaded) under incremental strains from 0.7 $\%$ to $4.0 \%$. Figure 3 (a-b) shows the results of the cyclic tests for the as-welded and heat-treated samples respectively. The cyclic stress-strain curves of the two samples were segmented into four zones. The segmented zones were filled with different colors to facilitate the visualization of the residual strain contributed by each zone.

As observed from Figure 3 (a-b), the local plastic deformation in the welded regions was well-covered by the red zone (loaded and unloaded from $1.5 \%$ strain) and green zone (loaded and unloaded from $2.5 \%$ ). It is noteworthy that the sum of residual strain contributed by the red and green zones in the aswelded sample was considerably higher than that in the heat-treated sample. This in turn indicates that the precipitation of $\mathrm{Ni}_{4} \mathrm{Ti}_{3}$ precipitates after PWHT can effectively suppress the local plastic deformation in the welded regions. On the other hand, the experimental results also provided strong evidence to support the argument that the residual strain in the as-welded sample was predominantly attributed to local plastic deformation, i.e. the sum of residual strain in the red and green zones contributed to about $83 \%$ of the total residual strain.

The as-welded sample tested at $50{ }^{\circ} \mathrm{C}$ showed a significant increase in the residual strain when compared with that tested at room temperature. Moreover, noticeable fluctuations (as pointed by the arrow in Figure 1b) were found in the stress plateau after the first cycle. As described by the ClausiusClapeyron relationship in the previous section, the plateau stress level increased with increasing test temperature. As such, the plateau stress level of the aswelded sample increased at $50{ }^{\circ} \mathrm{C}$, and raised to the level close to the fracture limit of the weld-joint (630 $\mathrm{MPa}$ ) (see Figure 1f). It is reasonable to speculate that local plastic deformation would be more severe when approaching to the fracture limit, causing an increase in the residual strain. Furthermore, such aggravated plastic deformation in the welded regions might subsequently interfere with the SIMT process and give rise to the fluctuations in the stress plateau. In contrast, the stress plateau of the heat-treated sample was very stable and no fluctuations can be found throughout the cyclic tests (as shown in Figure 1e). Moreover, the residual strain in the heat-treated sample was much less than that in the as-welded sample. The further reduction in the residual strain at $50{ }^{\circ} \mathrm{C}$ was attributed to the vanishing of detwinned martensite in the $\mathrm{BM}$ since the test temperature was higher than the $A_{F}$, i.e. all twinned martensite in the $\mathrm{BM}$ would completely transform into the austenite at $50{ }^{\circ} \mathrm{C}$.

\section{Conclusions}

In this study, the effect of different test temperatures: room temperature $\left(25{ }^{\circ} \mathrm{C}\right.$ or $\left.298 \mathrm{~K}\right), 50{ }^{\circ} \mathrm{C}(323 \mathrm{~K})$ and 
$75{ }^{\circ} \mathrm{C}(348 \mathrm{~K})$ on the functional properties of laserwelded NiTi samples before and after post-weld heattreatment (PWHT) were investigated using cyclic deformation tests. The experimental results indicate that the critical stress (or plateau stress level) to induce the martensitic transformation and the residual strain after the cyclic tests was highly associated with the test temperatures. The plateau stress level was found to increase with increasing test temperature. The residual strain of the as-welded sample was found to increase with increasing test temperature from room temperature to $50{ }^{\circ} \mathrm{C}(323 \mathrm{~K})$, whilst the heat-treated sample showed an opposite relation, i.e. the residual strain decreased with increasing test temperature in the given range. Both the as-welded and heat-treated samples were found to fracture in the first cycle during the cyclic tests at $75{ }^{\circ} \mathrm{C}(348 \mathrm{~K})$.

\section{References}

[1] Duerig, T., Pelton, A. \& Stockel, D. (1999) An overview of nitinol medical applications, Materials Science and Engineering A 273-275, 149-160.

[2] Morgan, N.B. (2004) Medical shape memory alloy applications - the market and its products, Materials Science and Engineering A 378, 16-23.

[3] Chau, E.T.F., Friend, C.M., Allen, D.M., Hora, J. \& Webster, J.R. (2006) A technical and economic appraisal of shape memory alloys for aerospace applications, Materials Science and Engineering A 438-440, 589-592.

[4] Chan, C.W. \& Man, H.C. (2011) Laser welding of thin foil nickel-titanium shape memory alloy, Optics and Lasers in Engineering 49, 121-126.

[5] Chan, C.W., Man, H.C. \& Yue, T.M. (2011) Effects of process parameters upon the shape memory and pseudo-elastic behaviours of laserwelded NiTi thin foil, Metallurgical and Materials Transactions A 42, 2264-2270.

[6] Chan, C.W., Man, H.C. \& Yue, T.M. (2012) Effect of post-weld heat-treatment on the microstructure and cyclic deformation behaviors of the laser-welded NiTi wires, Metallurgical and Materials Transactions A 43, 1956-1965.

[7] Chan, C.W., Man, H.C. \& Yue, T.M. (2012) Effect of annealing on the tensile deformation characteristics of laser-welded NiTi thin foil, Metals and Materials International 19 691-697.

[8] Nishida, M., Wayman, C.M. \& Honma, T. (1986) Precipitation processes in near-equiatomic TiNi shape memory alloys, Metallurgical Transactions A $17,1505-1515$.

[9] Viscuso, S. \& Pittaccio, S. (2012) Design and implementation of a portable amagnetic shape memory rotary actuator, Journal of Intelligent Material Systems and Structures 0, 1-19.

[10] Pelton, A.R., DiCello, J. \& Miyazaki, S. (2000) Optimization of processing and properties of medical-grade nitinol wire, Minimally Invasive Therapy \& Allied Technologies 9, 107-118. 